\title{
QSoft 705 as a New Finder of Qur'anic Words
}

\author{
$1^{\text {st }}$ Izzah Faizah Siti Rusydati Khaerani ${ }^{1}, 2^{\text {nd }}$ Rosihon Anwar ${ }^{1}, 3^{\text {rd }}$ Siti Chodijah $^{1}, 4^{\text {th }}$ \\ Hapikry Surya Permana ${ }^{2}$ \\ \{izzahfaizahsiti@uinsgd.ac.id¹, rosihonanwar@uinsgd.ac.id¹, sitichodijah1976@uinsgd.ac.id¹, \\ hapikrypermana6@gmail.com²\}
}

UIN Sunan Gunung Djati, Faculty of Ushuluddin, Bandung, Indonesia ${ }^{1}$, Universitas Padjajaran, Jatinangor, Sumedang, Indonesia ${ }^{2}$

\begin{abstract}
Ulum al-Qur'an studies the Qur'an and its related complex issues such as asbab al-nuzul, mufradat, fawathi al-suwar, and tikrar. This has made 'Ulum al-Qur'an a complicated subject to learn. Therefore, it requires a proper tool, which facilitates learners to study it. In this context, Qsoft 705 is an application that is able to help Qur'an analysts obtain accurate and valid data about the Qur'an. This article discusses how this application works in search for repeated words (tikrar) in the Qur'an. It is a descriptive analysis on how QSoft 705 helps users search related data to the Qur'an. The result shows that Qsoft 705 is able to search tikrar of verses, sentences, and words. Furthermore, Qsoft 705 also helps users know how many repeated words both in verses and sentences in the Qur'an.
\end{abstract}

Keywords: 'ulum al-qur'an, the sciences of the qur'an, data mining, tikrar, qsoft 705

\section{Introduction}

Data mining is defined as a process of finding data based on patterns or benefits that are intended to gain. In the process, data mining can be automatic or semi-automatic. Originally, it is an exploration and analysis of large amounts of data in order to find valid, useful, and easily understood data [1], [2]. It aims to find data patterns and relation- ships by using data analysis tools and model building technics. There are two main models in data mining: first, predictive model, which uses data with known results to develop a model that can be used to explicitly predict its value; second, descriptive model, which illustrates patterns of the existing data [2].

In practice, the purpose of data mining is to produce prediction and description. The main tasks for data mining are: (1) to classify data items (notes or examples) into one or several categories; (2) to provide input data that contain values for some unknown continuous variables; (3) to classify records according to predicted behavior or estimated value; (4) to determine which attributes or feature values are incorporated in data records; (5) to group data records or samples into a number of groups or subgroups; (6) to present data using technical visualizations in order to examine human patterns.

Looking at Qsoft 705, which was designed by Budi Pracoyo of Datastudio Bandung, we found that this application has an epistemological base that has been built by scholars of 'Ulumul Qur'an [5]. However, this application will not be meanigful if we cannot surf to do data mining creatively and accurately. Thus, it is necessary to disseminate data mining process 
provided by QSoft 705 in relation to its contribution to the development of Ulumul Qur'an studies. Qsoft 705 is able to trace repeated Qur'anic verses more detail than Qur'an scholars like As-Suyuthi and Zarqani.

\section{Literature Review}

Ulûm al-Qur'an is understood as a (collection or anthology) of science which contains all knowledge (al-ma'ärif) and the sciences ('ulüm) relating to the Qur'an [6]. That is, it is a collec- tion of "sciences" not a particular science. Because it is only a collection (anthology), then in fact position of each of these sciences is separated, although textually it is in a vast field of Islamic study. Hence 'Ulum al-Qur'ân in this first definition, is intended as a science which encompasses all knowledge discussed in the Qur'an from various perspectives. On the other hand, it is the codified discipline (al-fann al-mudaw-wan) in one perfect study. The experts of ' Ulûm al-Qur'an would usually explain the meaning of 'Ulûm al-Qur'an ana- lytically from every lafadz idhâfi, ie outlining meaning of words "' Ulûm" and "al-Qur'ân". As-Suyuthi in his book Al-Itqan fi Ulum Al-Qur'an presents 80 objects of Ulum Al- Qur'an study. Among them, asbab al-nuzul, mufradat, fawa-thi al-Suwar, ismiayah, filiyah, tikrar and others.

One of applications that can search for data extracting is Al- Hadi desktop application provided by Hadis Study Center (PKH). This application is able to filter texts of verses based on thematic and selected verses. Besides that, searching meaning of tafsir is also available in this application. Never- theless this application has not been able to find words that have semantics relations with other words, repeated words (tikrar), and also semantic field. Among applications that are able to extract data related to semantics or 'Ulum al-Qur'an such as tikrar, qashsh al-Qur'an, fawatih al-suwar, asabab nuzul, harf nida, kata qad inna dan laqad is Qsoft 705. It is designed to be used by all user from amateur until expert.

Mohammad Khubeb Siddiqui, Shams Naahid, and Moham- mad Nazrul Islam Khan conduct research on Qur'an web por- tal by applying data mining with title $A$ Review of Quranic Web Portals through Data Mining [7]. Furthermore, this re- search examines the access patterns of some websites by us- ing classification-based data mining by describing ROC and AUC plots, then predicts which most appropriate portals. This research finds that the Alexa website is an effective tool for obtaining required data about each of these areas of web portal Qur'an. The next research related to data mining is the research of Saeed Albukhitan, Ahmed Alnazer, and Tarek Helmy with title Semantic Annotation of Arabic Web Re- sources using Semantic Web Services. Although this research is not on the Qur'an study, the focus of the study is Arabic, of course, bias made as references for analyzing Arabic as a sec- ond reference [2]. The research finds that data mining through Arabic semantic web site services is not as comprehensive as the Latin web site services, so they recommend to build a se- mantic web applications and semantic search engines for Ar- abic.

Another research related to 'Ulum al-Qur'an is data mining Qur'an conducted by Hapikry Surya Permana and Elvi Citraresmana [8]. The research focuses pragmatics to describe the frequentative verb of directive illocutionary acts used in the English translation of the holy Qur'an by Muhammad Asad. with title Directive Illocutionary Acts Used in the Eng- lish Translation of the Holy Quran by Muhammad Asad: A Corpus Based Study. The research finds that commanding and requesting are the kinds of directive illocutionary acts oc- curred in the Qur'an. Commanding occurs 575 times in the English translation of the holy Qur'an by Muhammad Asad divided into five frequentative verbs. 


\section{Methodology}

This research applies a qualitative research. According to Djadjasudarma, descriptive analysis method is a method that can descriptively provide characteristics, properties and image data through data selection, after the data is collected. In this research, there are the three stages to be done, namely: data provision, data analysis, and presentation or formulation of the analysis result [9].

This research also applies technique of data collecting of QSoft. QSoft is a Quran software structured in a data-base query, enabling users to get information on a wider Quranic data easily, quickly and accurately. Heretofore Data studio has developed Qsoft version 7.05 to 7.09 with amounts of data available is not less than 25 million data related to the Qur'an and Tafsir. This application is able to search, sift, sort, and calculate on all elements contained in the Qur'an, [5] from juz, verses, sentences, words, letters to thematic searches and objects of study discussed in 'ulum Qur'an such as tikrar, idzaa word, innaa word, qad, laqad, nakirah makrifat, asbab nuzul, makki madani and others that can be explored care- fully by the user.

In this research, the writers focus only repeated words (tikrār) occurred in Qur'an by taking some samples to show how Qsoft 705 works to search tikrar in ayah, tikrar in sentence, and tikrar in verses.

\section{Result and Discussion}

\subsection{Tikrar in Verse}

Tikrār fi Al-Qur'ān is more than twice repetation of words, sentences or verses, whether literally or semantically with particular reasons and purposes [7]. In the following, we demonstrate how many times verse waylun yawma-idzin lilmukadz-dzibin(a) exists in the Qur'an and where the verse is placed.

There are three research technique to find tikrar in verse by using Qsoft 705 generally:

- $\quad$ Put the curson on Repeating Column.

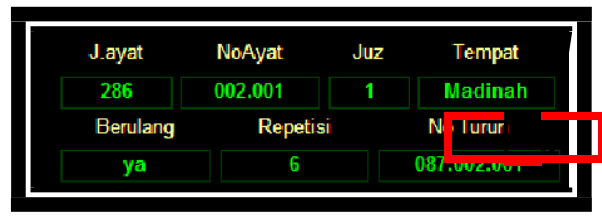

Figure 1. Repeating Column

- $\quad$ Click Selection

- Then choose and click Does Not Equal Bank to show re- peated verses in the Qur'an. 


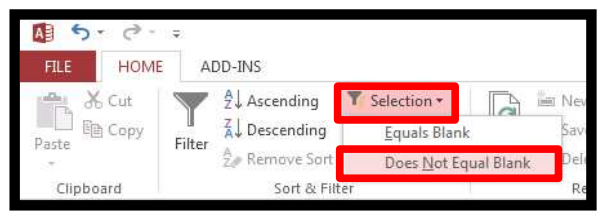

Figure 2. Does Not Equal Bank

The mark will appear on repeating column and we can see how many times the verse exists by looking at repetition column. Furthermore, by looking at Record column, we get information how many repeated verses exist in the Qur'an. According to the result that there are 282 repeated verses in Qur'an. There are 53 verses descended in Medina and 229 verses descended in Makah.

In the following table we show how many times verse waylun yawma-idzin lilmukadzdzibin(a) exists in the Qur'an and where the verse placed.

Table 1. Tikrar in Verse Waylun Yawma-Idzinlilmukadz-Dzibin(A)

\begin{tabular}{ccc}
\hline Verse & Frequentative & Ayat \\
& & $077.049,077.047$, \\
Al Mursalaat & \multirow{2}{*}{10} & $077.045,077.040$, \\
& & $077.037,077.034$, \\
& & $077.028,077.024$, \\
Al Muthaffifin & 1 & $077.019,077.015$ \\
\hline
\end{tabular}

The result show that verse waylun yawma-idzin lilmukadz-dzibin(a) exists eleven times in the Qur'an. 10 times exist in Surah Al Mursalaat in 077.049, 077.047, 077.045, 077.040, 077.037, 077.034, 077.028, 077.024, 077.019, and 077.015.

Al Muthaffifin is another place where verse waylun yawma-idzin lilmukadz-dzibin(a) exists only one time. Furthermore, the repeated verse is descended in Makah.

The above paragraph describes how Qsoft 705 search tikrar in verse, how to calculate the frequentative repeated verses in Qur'an, where the repeated verses placed in Qur'an whether in Makah or Medina or both.

\subsection{Tikrar in Sentence}

In the Qur'an, sometime we find that one verse contains one or more sentences. Waylun yawma-idzin lilmukadz-dzibin(a) can be categorized as a verse and a sentence. Therefore, in this data we find the same result as we find in the first result above. Nevertheless, we apply another research technique to find data.

In the following table we show how many times verse way-lun yawma-idzin lilmukadzdzibin(a) exists in the Qur'an and where the verse placed.

1. Search verse waylun yawma-idzin lilmukadz-dzibin(a) by using search bottom or press CTRL+F on keyboard. Then write the verse and click find to get the verse.

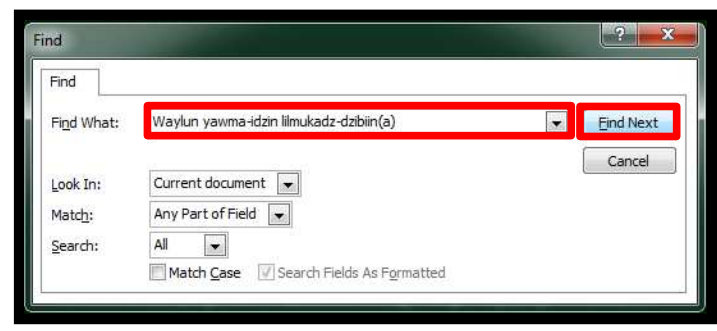


Figure 3. Interface Search Words

2. Blocking the words without space before and after the words.

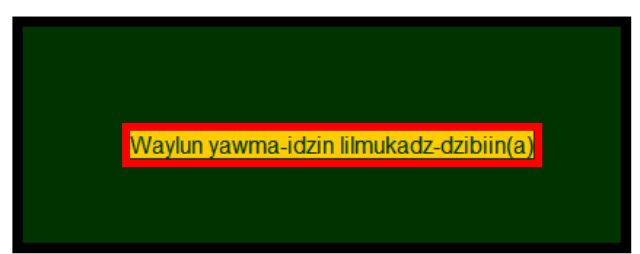

Figure 4. Interface Blocking Words

3. Click selection and contain "waylun yawma-idzin lilmukadz-dzibīn(a)

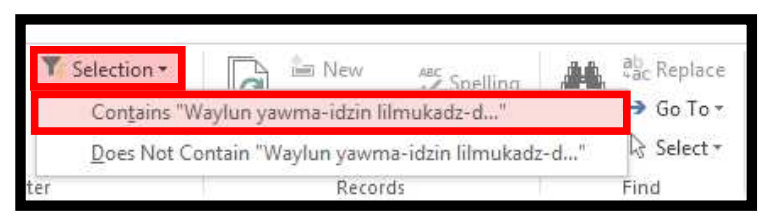

Figure 5. Interface Selection Words

4. By looking at record column, we get information that there are 11 repeated words waylun yawma-idzin lilmukadz- dzibīn(a) in Qur'an

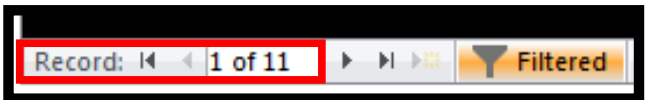

Figure 6. Interface Filtered

Table 2. Tikrar in Sentence

\begin{tabular}{ccc}
\hline Verse & Frequentative & Ayat \\
\hline & & $077.049,077.047$, \\
Al Mursalaat & \multirow{2}{*}{10} & $077.045,077.040$, \\
& & $077.037,077.034$, \\
& & $077.028,077.024$, \\
Al Muthaffifin & 1 & $077.019,077.015$ \\
\hline
\end{tabular}

The result show that verse waylun yawma-idzin lilmukadz-dzibin(a) exists eleven times in the Qur'an. 10 times exist in Surah Al Mursalaat in 077.049, 077.047, 077.045, 077.040, 077.037, 077.034, 077.028, 077.024, 077.019, and 077.015. 
Al Muthaffifin is another place where verse waylun yawma-idzin lilmukadz-dzibin(a) exists only one time. Furthermore, the repeated verse is descended in Makah.

The above paragraph describes how Qsoft 705 search tikrar in verse, how to calculate the frequentative repeated verses in Qur'an, where the repeated verses placed in Qur'an whether in Makah or Medina or both.

\subsection{Tikrar in Ayat}

In the following, we find how many times words lilmukadz-dzibin(a) exists in the Qur'an and where the verse is placed. There are three research technique to find tikrar in verse by using Qsoft 705 generally:

- Search words lilmukadz-dzibin(a) by using search bottom or press CTRL+F on keyboard. Then write the verse and click find to get the verse.

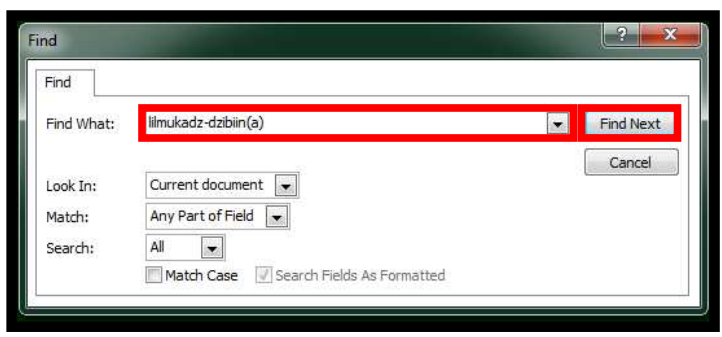

Figure 7. Interface Search Words

- $\quad$ Blocking the words without space before and after the words.

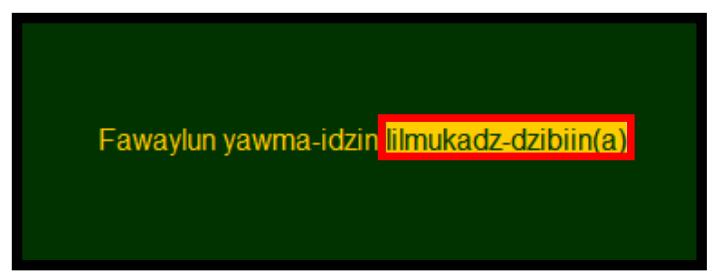

Figure 8. Interface Blocking Words

- Click selection and contain "lilmukadz-dzibin(a)"

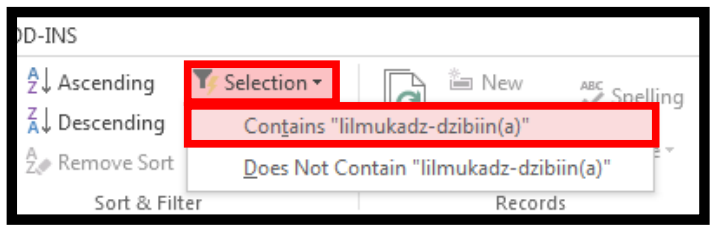


Figure 9. Interface Selection Words

- By looking at Record column, we get information that there are 12 repeated words lilmukadz-dzibin(a) in Qur'an.

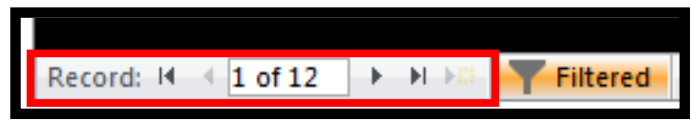

Figure 10. Interface Filtered

According to the result, words lilmukadz-dzibin(a) exists 12 times in the Qur'an. 11 ayat are began with word $w a$ - and 1 ayah is began with word $f a-$.

The twelfth words lilmukadz-dzibin(a) began with wa- is placed 10 times in Surah $\mathrm{Al}$ Mursalaat, 1 times in Surah Al Muthaffifin, and one word lilmukadz-dzibin(a) began with fais placed in Surah Ath-Thuur. All of them are descended in Makah.

\section{Conclusion}

The study of data mining greatly influences the epistemol- ogy of the study of the sciences of the Qur'an ('Ulum al-Qur'an). Studying the sciences of the Qur'an was complicated, but through Qsoft 705 has made this easy and quick to learn. It It is able to show learners Qur'anic data more completely than traditional ways of search for Qur'anic terms. Moreover, it provides learners with a unique experience in obtaining information science. This information will form a systematic and comprehensive knowledge which is able to give birth to wisdom in understanding Qur'anic texts.

Furthermore, Qsoft 705 opens up a door to those interested in 'Ulum al-Qur'an to develop research that contributes to the sciences of the Qur'an. It is able to bring back al-Qur'an as a source of thinking.

\section{References}

[1] Y. Mardi, "Data Mining: Klasifikasi Menggunakan Algoritma C4.5," Edik Inform., vol. 2, no. 2, pp. 213-219, 2016.

[2] S. Albukhitan, A. Alnazer, and T. Helmy, "Semantic Annotation of Arabic Web Resources Using Semantic Web Services," Procedia Comput. Sci., vol. 83, pp. 504-511, 2016.

[3] N. Iam-On and T. Boongoen, "Generating descriptive model for student dropout: a review of clustering approach," Human-centric Comput. Inf. Sci., vol. 7, no. 1, p. 1, Dec. 2017.

[4] E. Stattner and M. Collard, "Descriptive Modeling of Social Networks," Procedia Comput. Sci., vol. 52, pp. 226-233, 2015.

[5] B. Pracoyo and A. Nugraha, Buku Panduan QSoft versi 7.05. Bandung: Data studio Badung, 2012.

[6] Al-Zarkasyi, al-Burhan fi "Ulûm al-Qur"ân. Beirut: dar al-Fikr, 1980.

[7] M. K. Siddiqui, "A Review of Quranic Web Portals Through Data Mining," VAWKUM Trans. Comput. Sci., vol. 5, no. 2, pp. 1-7, 2014. 
[8] H. S. Permana and E. Citraresmana, "Directive Illocutionary Acts Used in the English Translation of the Holy Quran by Muhammad Asad: A Corpus Based Study," in he 6th International Conference on Multidisciplinary Research (ICMR), 2017, pp. 582-589.

[9] F. Djajasudarma, Metode Linguistik: Ancangan Metode Penelitian dan Kajian. Jakarta: Refika Aditama, 1993. 